\title{
REGULATING THE AUDIT QUALITY AND DEPROFESSIONALISATION OF THE AUDITING PROFESSION
}

\author{
Noor Adwa Sulaiman, Rusnah Muhamad and Mazni Abdullah
}

\begin{abstract}
There has been considerable criticism of the auditing profession from the public following a series of corporate failures. Consequently, this has led to reform in the auditing regulatory framework. This study examines the impact of the auditing regulatory reforms, in particular, the impact of the independent audit inspection on the auditing profession. This is ascertained by analysing the views expressed in response to the discussion paper titled, 'Promoting Audit Quality' published by the Financial Reporting Council (FRC), and from interviews with selected audit partners in the United Kingdom. Using deprofessionalisation as a framework, the analysis highlights the conflict of jurisdiction over the work between the regulator and the audit practitioners, the challenge to the profession's control over the professional knowledge base by the regulator, and the crisis of ideology of the members of the profession. The evidence suggests a trend towards deprofessionalisation of the auditing profession that may diminish auditors' professional attributes and their social role to the public.
\end{abstract}

Keywords: audit quality review, inspection, audit quality, deprofessionalisation JEL Classification: M41, M42, M48, L84

\section{Introduction}

Over the years, auditing has been recognised as a profession based on the arguments of its members, in respect of their expertise and objectivity, and the 'crucialness' of their role to the public, such as investors and lending institutions (Burns and Haga, 1977; Flint, 1998). The role of auditors is to provide independent verification of financial statements, a process which involves the accumulation and evaluation of audit evidence. This evidence then becomes the basis for the auditors to form their professional opinion on the financial statements. The result of the process, that is, the audit opinion, is believed to enhance the credibility and quality of the financial statements (Gul et al., 2003). An independent audit is thought to protect the economic interests of the investors and other interested parties by enhancing the value of the financial statements prepared by the managers.

Corresponding author: Dr Noor Adwa Sulaiman is a Senior Lecturer in the Faculty of Business and Accountancy, University of Malaya, email: adwa@um.edu.my. Datin Dr Rusnah Muhamad and Dr Mazni Abdullah are Associate Professor and Senior Lecturer in the Faculty of Business and Accountancy, University of Malaya, respectively. 
Moizer (2005) suggests that the perceived value of the auditors by the public would depend on the quality of the auditors' work performance, which, in turn, is related to their ability to detect and report material misstatements and/or omissions of accounting matters. Their ability depends on auditor's professional attributes, such as technical competence, knowledge, experience, industry specialisation and technological proficiency. These professional attributes are acquired by way of advanced education, training and experience, which characterise auditors as members of a profession (Burns and Haga, 1977).

The profession enjoys a relatively high status in society through its specialist knowledge and service, and its own monitoring procedures and standards of work performance. Nonetheless, corporate collapses (such as Enron and Parmalat) have raised concerns over the standing of members' performance and people's confidence in the auditing profession. In consequence, a reform in the auditing regime was undertaken through the establishment of the independent audit inspection. The reforms have brought an end to the self-regulation by the profession in favour of the independent oversight and regulation of the accounting profession (Turley, 2008, p. 210). The independent oversight (such as the Public Company Accounting Oversight Board (PCAOB) and the Audit Quality Review (AQR) (formerly known as Audit Inspection Unit (AIU)) has increasingly been seen as an important element in the regulatory landscape of auditing that aims to advance high professional audit standards and improve the quality of audit performance (SOX, 2002; EC, 2010, p.14).

The reforms in auditing in recent years have spurred a growing body of research concerning the potential impact of the independent inspections on auditing. A review of the extant literature reveals that various research has been conducted pertaining to the impact of the independent inspection on the financial reporting quality (Lobo and Zhou, 2006; Gramling et al., 2011; Carcello et al., 2011) or perceptions of audit clients and small practising audit firms on independent inspections (Lennox and Pittman, 2010; Daugherty and Tervo, 2010). In line with the calls made for more research on the reforms to audit regulation (Defond and Francis, 2005; Nagy and Cenker, 2007; Defond, 2010), this study provides insights into the impact of independent inspections on the auditing profession gathered through views expressed in letters and interviews.

The article is organized as follows. Section 2 provides the conceptual framework of this study. The method and data collection are described in Section 3, followed by the analysis and results (Section 4). Finally, we conclude with a discussion of the implications together with suggestions for future research. 


\section{Professionalisation and Deprofessionalisation}

Professionalism is closely related to the underlying facet of auditing, which emerges when audit practitioners perceive that their role should adhere to the standards of the professional or expert group of which they are members (Burns and Haga, 1977; Miner et al., 1994). From this perspective, one needs first to understand that auditing is a professional service that concerns the possession of knowledge or expertise and the need to display appropriate behaviour in the interests of the public (Grey, 1998). Thus, how auditors perceive their roles has the potential to influence what they consider to be a legitimate and acceptable knowledge base, and practice. These are reflected in, for example, codified rules and regulations, education, training, audit methodology and quality control procedures, and, consequently, their actions, which influence the institutional significance of the auditing process and auditors (Power, 1996; Cooper and Robson, 2006).

The professionalism of auditors primarily relates to the professional attributes, values and appearance that individual auditors have, such as judgement, expertise, competence, knowledge, interpersonal skills, ethics and independence, which may influence their performance in executing audit responsibilities. These 'symbols' of professionalism are important for the acceptable representation of the work practices of auditors, and, to some extent, of the quality (Power, 1996). Furthermore, the auditing profession emphasises the procedural aspects of an audit (such as, sampling, working papers and audit planning) to signify audit quality when the quality of the output is unobservable within the practice as well as to those outside. Both the appearance and process are important to symbolise quality in their claim to the knowledge base of auditing and associated work practices (Power, 2003), as well as to maintain the status quo, restrict competition and the intervention of regulation on the profession (Hines, 1989, p.89). The procedures to monitor its members, such as peer review, and the existence of standards and guidelines (e.g. codes of conduct), are considered to be important in signalling that a certain standard of quality has been achieved and maintained in the work performance of its members and the autonomy of their work.

In examining deprofessionalisation of the auditing profession, our analysis is informed by the deprofessionalisation hypothesis proposed by Haugh (1973). According to Haugh (1973, p.197), a profession may experience a process of deprofessionalization through the diminution of their monopoly over knowledge and public belief in their service ethos. Over the years, it is argued that the auditing profession has shifted its ideology of 'public interest' as its service ethos to accommodate the commercial interests of the audit firms (Hanlon, 1994). Baker (2008) highlights the distortive aspects of the ideology that are caused by the economic interests of the profession rather than those of the public, which leads to a conflict in values and practices within the profession. Some researchers have argued that the diminidhing of the status of auditing as a profession has led to a crisis about the role of the auditor and the quality of the 
audit work (Humphrey and Moizer, 1990; Sikka et al., 2009). For example, the time budget pressure, which is caused by the emphasis on revenue, can have a negative impact on the audit quality through auditor's engaging in dysfunctional behaviour, such as reducing the sample size or prematurely signing-off the audit report (Kelley et al., 1999; Herrbach, 2001). The commercial interests of the audit firm may also have a negative impact on the appearance and actual audit quality by reducing the ability of auditors to maintain their independence because of the significant amount of non-audit fees received from the audit client (Pany and Reckers, 1984).

Haugh (1973) recognises that deprofessionalization also involves an erosion of the profession's autonomy and authority over the work. It has been suggested that the auditing profession has lost some of its autonomy and authority through statutory regulation of accounting firms that limit the selfregulation (Anantharaman, 2012). The autonomy of professional auditors over their work (such as peer review system) has been weakened because the quality control systems and work performance of accounting firms are now being monitored by an independent regulatory body. There is also evidence to suggest that the authority of the work of professional auditors is being questioned, which is reflected in the difference of views between the PCAOB and audit firms in terms of accounting and auditing areas that require substantial professional judgement and/or documentation issues (Daugherty and Tervo, 2010; Blankley et al., 2012). Nagy and Cenker (2007) conducted interviews with auditors in the United States (US) and show that the increased regulation following the implementation of the Sarbanes Oxley Act (SOX) (2002) has impacted on the professional judgement of auditors and the overall audit quality through creating a compliance approach to audit that hinders auditors' reasoning capabilities. An earlier study by Francis (1994) indicates that the new regulations in response to accounting scandals have led to highly standardised and structured audit approaches that potentially reduce the audit quality by limiting the dependence on professional judgement. Similarly, Hatherly (1999) suggests that the increased regulation and economic pressure in the auditing setting might displace some level of professional judgement from auditing to achieve the cost effectiveness that may potentially affects the auditor's performance.

\section{Methodology}

The objectives of this study were addressed through the analysis of responses to a discussion paper titled 'Promoting Audit Quality', which was issued by the FRC in 2006, and interviews conducted with eleven audit partners in the United Kingdom (UK). Thirty-nine sets of responses were received in response to the discussion paper: eight from audit firms, ten from professional bodies, nine from institutional investors, two from the corporate sector and ten from other interested parties. Of the eight sets of responses received from the audit firms, four were received from the Big Four and four from middle tier firms. All 
responses to the discussion paper were analysed. Nonetheless, the analysis focuses on the responses by the audit firms and professional bodies that represent the auditing profession.

Comment letters submitted to the discussion paper represent a significant available source of evidence on regulating audit quality, as they comprise the views expressed by a group of interested parties, and, therefore, are worth analysing. The respondents made a significant number of comments in their covering letters and response pages, which were analysed using content analysis. This is an accepted approach to textual investigation for identifying the occurrence, patterns or themes within its specific contexts (Berg, 2006). The issues identified in the documentary analysis were used to develop an interview guide, so that the relevant themes were covered during the interviews with the audit partners of the study. In this way the interviews could be structured around those matters for which there was already some evidence of their relevance to the understanding of the impact of the regulatory reforms on the auditing profession.

The study also carried out eleven semi-structured interviews with audit engagement partners within a period of three months. Eight of the interviewees were from Big Four firms and the remaining three from mid-tier firms. Ten of the audit partners were male, with the majority aged 48-57 years and having a professional qualification. All of the audit partners had auditing experience of more than 20 years. The interviews were digitally recorded and a few notes were taken in order to promote an open dialogue on the matters being discussed. The transcripts were reread to improve familiarity with the data. In this study, the analysis of the data involved searching and identifying for recurring themes and patterns together with consistencies and meanings in the information (Silverman, 2006).

\section{Analysis and Discussion}

This section outlines the findings from the analysis of the comments pertaining to the discussion paper and the interviews conducted with the audit partners.

\subsection{Deprofessionalisation of the accounting profession?}

Quality of people - expertise and professional judgement is the traditional sphere in auditing. Central to this claim, the audit firms and professional bodies argue that the changes in audit regulation may constitute a threat to that core value of the audit profession. In general, the analysis of the responses to the discussion paper (Table 1) and the evidence from the interviews highlight the significant concern of the respondents in terms of the impact of the changes in the audit regulation that may devalue a core area of expertise. Furthermore, it was argued that the changes to the nature of audit practices, which are more to do with the box ticking approach in audit performance, are detrimental to the professional judgement of auditors. 
The audit firms and the professional bodies frequently stressed points concerning the potential adverse impact of the current regulatory environment on the quality of people in the audit firm. The audit practitioners argued that complex accounting rules and auditing standards, and the check-list audit approach resulted in changing the nature of audit work to a more compliance based activity that had an unfavourable impact on the attractiveness of the profession to hire and retain quality audit staff. The changes in audit regulation have influenced the nature of audit in that it has become more procedural to reflect regulatory compliance (Nagy and Cenker, 2007). In addition, intrusive audit regulations, unbalanced reviews by the regulators and the threat of litigation have reduced the attractiveness of the profession to attract and retain quality audit staff.

Table 1

\begin{tabular}{|c|c|c|c|c|c|}
\hline Respondents & $\begin{array}{l}\text { Audit } \\
\text { Firms }\end{array}$ & $\begin{array}{l}\text { Professional } \\
\text { Bodies }\end{array}$ & $\begin{array}{l}\text { Institutional } \\
\text { Investors }\end{array}$ & Corporate & Others \\
\hline Total number of respondents & 8 & 10 & 9 & 2 & 10 \\
\hline \multicolumn{6}{|l|}{ Issues } \\
\hline $\begin{array}{l}\text { Regulation creates box ticking } \\
\text { mentality culture among the audit } \\
\text { practitioners }\end{array}$ & 8 & 10 & 0 & 1 & 1 \\
\hline $\begin{array}{l}\text { Regulation emphasises too much } \\
\text { on the audit documentation }\end{array}$ & 8 & 10 & 0 & 0 & 0 \\
\hline $\begin{array}{l}\text { Public accounting firms focus on } \\
\text { commercial aspects of their } \\
\text { business }\end{array}$ & 0 & 0 & 3 & 0 & 1 \\
\hline $\begin{array}{l}\text { Regulation reduces the } \\
\text { attractiveness of the profession }\end{array}$ & 7 & 9 & 2 & 0 & 1 \\
\hline $\begin{array}{l}\text { Regulation promotes the } \\
\text { prescriptive audit approach rather } \\
\text { than the use of auditor's } \\
\text { professional judgement }\end{array}$ & 8 & 8 & 3 & 2 & 2 \\
\hline
\end{tabular}

The audit practitioners expressed deep concern that the current efforts undertaken by the $\mathrm{AQR}$ are moving away from the principles to a rule based audit approach that might emphasise a box ticking approach or compliance at the expense of their professional judgement. The findings from interviews with auditors in the US by Nagy and Cenker (2007) support the claim that the changes in audit regulation influence the nature of audit and that it has become more procedural to reflect the regulatory compliance. This expression of discomfort by the audit practitioners may be also construed as the effect that regulation has on diminishing the professional judgement of auditors or the 'deprofessionalisation' of the audit profession, which is related to the value of an audit. This is reflected by the following comments made in response to the discussion paper and by the interviewees. 
"The approach of the regulator has a direct effect on the culture of an audit firm and a relentless focus on documentation will drive a culture in the audit firms that detracts from evidence gathering and making judgements" (Discussion paper-PWC).

"The auditors will not be providing the appropriate challenge to clients and providing appropriate reporting if it is just a box ticking process" (Interview-Audit Partner1).

"There is greater and greater emphasis on what is written down rather than what is actually done and the judgments that are formed" (Interview-Audit Partner 11).

Several views on the inspection body were expressed by the interviewees. In general, most of the audit partners tended to voice feelings of unease when discussing the inspection process. The Audit Quality Review approach was perceived as being burdensome and leading to overwhelming workloads. Some of the audit partners felt that a lack of beneficial feedback was given in the review. The audit partners also commented on the unpleasant experience of working with the inspection body. In addition, analysis of the responses to the discussion paper and evidence from the interviews reveal how meeting the expectations of the regulator has created an additional challenge to accounting firms, which highlights the struggle of the practitioners to attain a balance between spending time on documentation and the audit process itself. This situation has led to a disagreement with the audit practitioners concerning the adequacy of the audit evidence documented in the audit working paper. Furthermore, the majority of the audit partners were apprehensive about the impact of the $\mathrm{AQR}$ on the cost and benefits associated with the inspection. They suggested that they need to spend considerable time and provide the necessary staff to meet the requirements of the AQR, which affects the cost of the audit. The situation has created additional pressure on audit firms because increases in audit fees do not always correspond with the audit costs. The following quotation illustrates the views concerning this issue:

"It is a pretty onerous... and... unpleasant experience to be reviewed by the AIU and I am not sure that is actually how it should be. I fully acknowledge they have got a job to do and I do not think anybody would want them to not be on the side of high quality audits; however, equally I think they ought to be coming from the perspective that you are innocent until proven guilty rather than "actually this is a bad audit and now you have got to prove that it's a good audit", which, personally, I think is the wrong way to come at it" (Interview-Audit Partner 3). 
"We consider that having an overly complex financial reporting regime can have a detrimental impact on the audit quality as it can mean that partners and senior staff spend too much time on accounting issues or in preparing documentation for the benefit of regulators. We understand that this has been an increasing problem for firms" (Discussion Paper-ICAEW).

Another significant concern of the audit partners in relation to the regime of inspection is the impact of public reporting, that is, the AQR public reports on the perception of the users' concerning the audit services. In particular, they expressed concern that the public would misinterpret the information published in the report, which might affect public confidence and trust concerning the quality of the services that they offer. This might also affect the business of the audit firm. The audit partners also believed that the regime of inspection does not have a significant impact on the commercial value of audit firms in relation to their audit client. In the analysis, it is evident that the audit practitioners regarded themselves as a 'servant to their master'. In this case, the majority of the audit practitioners considered the importance of commercial objectives of the audit firms (that is their audit clients) rather than the interest of the public in their work performance. This perception is illustrated by the following comments:

"My concern is that the man on the Clapham Omnibus may see some issues as being more severe than they really are in practice if they are misunderstood in a report... I do think that if people misunderstand things it might just be some documentation around something; quite a small matter could be perceived by an external reader thinking "oh my gosh, you know x, y or z firm does not know how to do this", so if it is not well written or the issue is not clearly understood it could be very detrimental to the firm's market position" (Interview-Audit Partner 9).

"I do not think regulation will necessarily improve the quality or indeed that it will help the audit clients get a better service..." (Interview-Audit Partner 7).

"We consider that one contributory factor in recent years to a decline in audit quality is the way audit firms have tended to shift to a more aggressive, commercial business model' (Discussion PaperInvestment Management Association).

Overall, the majority of the respondents expressed their deep concern about the effect of excessive and overly complex standards and regulation that is shifting auditing from principles to rules based approaches. As a result, the majority of the respondents believed that as the audit approach becomes more 
prescriptive, which promotes compliance exercises rather than the use of professional judgement, it would significantly affect the effectiveness of the audit process and the overall assessment of the financial statements, and, thus the delivery of a high audit quality. Analysis of the responses shows that the respondents were inclined to highlight concerns about unfavourable impact of the current regulatory environment on the expertise and judgement of the auditors. To summarise, there were strong views from the audit practitioners concerning the impact of the regime of inspection on the elements of professionalism. For instance, they indicated the negative impact of the inspection in three major areas. First, they were concerned about the impact of the regime of inspection on the professional quality or the audit judgement because of the shift in the nature of the audit from principles to a rule based audit approach. Second, the audit partners also conveyed concern about the cost that was associated with the inspection that might outweigh its benefit and may affect the efficiency of the audit, and commercial objective of the audit firm. Finally, they were apprehensive about the impact of the AQR's public reporting on the confidence and trust of the users concerning the audit profession.

\section{Conclusion}

This study provides insights into areas that are potentially relevant for further investigation and that may enhance knowledge in terms of the impact of regulating the audit quality in practice. The analysis of the findings suggests that regulating audit quality contributes to deprofessionalisation of the accounting profession. For example, increasing regulatory intervention in auditors' work performance (audit judgements and audit documentation) has clearly reduced the dominance of the auditing profession in various aspects of auditing practices. The study shows the unintended consequences of the inspection process for audit quality on the auditing profession. The implications relate to how policymakers should be able to address the issue, and, accordingly, take action related to the promotion of audit quality. The role of the regulator should give appropriate consideration to how regulating audit quality could promote high quality audit performance.

With regard to the audit quality literature, this study enhances the understanding of the impact of the audit regulatory reform on the auditing profession. In addition, this study is drawn from the context of auditing within the UK, whereas much of the prior research has been dominated by studies conducted with reference to the US environment (as evidenced in, for example, the surveys of Watkins et al., 2004 and Francis, 2004). The issues reported in this article therefore complement existing research through opening up the impact of the auditing reform to the members of the auditing profession.

Whilst this study may have provided theoretical and empirical contributions in several respects, like any research, it is subject to certain limitations. Principally these relate to the scope of the groups included in the research and the extent of coverage of these groups. Future research could focus 
on the perceptions of other participants in the audit market (such as the preparers of the financial statements) concerning the impact of the audit regulatory reform on the audit profession and the performance of its members.

\section{References}

Anantharaman, D. (2012). How Objective is Peer Review? Evidence from SelfRegulation of the Accounting Profession. SSRN Working Paper Series.

Baker, C.R. (2008). Ideological Reactions to Sarbanes-Oxley. Accounting Forum, 32(2): 114-124.

Berg, B.L. (2006). Qualitative Research Methods for the Social Sciences. Pearson Education (US) Prentice Hall.

Blankley, A.I., Hurtt, D.N. and MacGregor, J.E. (2012). Abnormal audit fees and restatements. Auditing, 31(1): 79-96.

Burns, D.C. and Haga, W.J. (1977). Much Ado about Professionalism: A Second Look at Accounting. The Accounting Review, 52(3):705-715.

Carcello, J.V., Hollingsworth, C. and Mastrolia, S.A. (2011) The Effect of PCAOB Inspections on Big 4 Audit Quality, Research in Accounting Regulation, 23: 85-96.

Cooper, D.J. and Robson, K. (2006). Accounting, Professions and Regulation: Locating the Sites of Professionalization. Accounting, Organizations and Society, 31(4-5): 415:444.

Daugherty, B. and Tervo, W. (2010) PCAOB Inspections of Smaller CPA Firms: The Perspective of Inspected Firms, Accounting Horizons, 24(2): 189-219.

Defond, M.L. (2010) How Should the Auditors Be Audited? Comparing the PCAOB Inspections with the AICPA Peer Reviews, Journal of Accounting and Economics, 49(1-2): 104-108.

DeFond, M.L. and Francis, J.R. (2005) Audit Research After Sarbanes-Oxley. Auditing: A Journal of Practice and Theory, 24(Supplement): 5-30.

EC (2010). Green Paper, Audit Policy: Lessons from the Crisis. Available at: http://ec.europa.eu/internal_market/consultations/2010/green_paper_audit_ en.htm [Accessed on 06/10/2013]

Flint, D. (1988). Philosophy and Principles of Auditing. London: Macmillan Education Ltd.

Francis, J.R. (1994). Auditing, Hermeneutics, and Subjectivity. Accounting, Organizations and Society, 19(3): 235-269.

Francis, J.R. (2004). What Do We Know About Audit Quality? The British Accounting Review, 36(4): 345-368.

Gramling, A.A., Krishnan, J. and Zhang, Y. (2011). PCAOB Inspections of SmallAccounting Firms and Auditor Reporting Decisions, Working paper, Kennesaw State University.

Grey, C. (1998). On Being a Professional in a "Big Six" Firm. Accounting, Organizations and Society, 23(5/6): 569-587. 
Gul, F.A., Sun, S.Y.J. and Judy S.L.T. (2003). Audit Quality, Earnings, and the Shanghai Stock Market Reaction. Journal of Accounting, Auditing \& Finance, 18(3): 411-427.

Hanlon, G. (1994). The Commercialisation of Accountancy Flexible Accumulation and the Transformation of the Service Class. Houndmills, Basingstoke, Hampshire: The MacMillan Press Ltd.

Hatherly, D.J. (1999). The Future of Auditing: The Debate in the UK. The European Accounting Review, 8(1): 51-65.

Haugh, M. (1973). Deprofessionalization: An Alternative Hypothesis for the Future. Sociological Review Monograph, 20: 195-211.

Herrbach, O. (2001). Audit Quality, Auditor Behaviour and the Psychological Contract. The European Accounting Review, 10(4): 787-802.

Hines, R.D. (1989). Financial Accounting Knowledge, Conceptual Framework Projects and the Social Construction of the Accounting Profession. Accounting, Auditing \& Accountability Journal, 2(2): 72-92.

Humphrey, C. and Moizer, P. (1990). From Techniques to Ideologies: An Alternative Perspective on the Audit Function. Critical Perspectives on Accounting, 1(3): 217-238.

Kelley, T., Margheim, L. and Pattison, D. (1999). Survey on the Differential Effects of Time Deadline Pressure Versus Time Budget Pressure on Auditor Behaviour. The Journal of Applied Business Research, 15(4): 117128.

Lennox, C. and Pittman, J. (2010) Auditing the auditors: evidence on the recent reforms to the external monitoring of audit firms. Journal of Accounting and Economics, 49: 84-103.

Lobo, G. and Zhou, J. (2006). Did Conservatism in Financial Reporting Increase After the Sarbanes-Oxley Act? Initial Evidence. Accounting Horizons, 20(1): 57-73.

Miner, J.B. Crane, D.P. and Vandenberg, R.J. (1994). Congruence and Fit in Professional Role Motivation Theory. Organization Science, 5(1): 86-97.

Moizer, P. (2005). Governance and Auditing. Cheltenham UK: Edward Elgar Publishing Limited.

Nagy, A.L. and Cenker, W.J. (2007). Accounting Firms Cautiously Maneuver in the New Audit Environment - a Note. Managerial Auditing Journal, 22(2): 218-225.

Pany, K. and Reckers, P.M.J. (1984). Non-Audit Services and Auditor Independence - A Continuing Problem. Auditing: A Journal of Practice \& Theory, 3(2): 89-97.

Power, M., (1996). Making Things Auditable. Accounting, Organizations and Society, 21(2/3): 289-315.

Power, M.K., (2003). Auditing and the Production of Legitimacy. Accounting, Organizations and Society, 28(4): 379-394.

Sarbanes Oxley Act (2002). Available at: news.findlaw.com/cnn/docs/gwbush/sarbanesoxley072302.pdf [Accessed on $22 / 06 / 2013]$ 
Sikka, P., Filling, S. and Liew, P. (2009). The Audit Crunch: Reforming Auditing. Managerial Auditing Journal, 24(2): 135-156.

Silverman, D. (2006). Interpreting Qualitative Data, Sage Publications Ltd, 1 Oliver's Yard, 55 City Road, London EC1Y 1SP.

Turley, S. (2008). Developments in the Framework of Auditing Regulation in the United Kingdom. In: Quick, R., Turley, S. and Willekens, M. (eds). Auditing, Trust and Governance Developing regulation in Europe. Abingdon: Routledge, 205-222.

Watkins, A.L., Hillison, W. and Morecroft, S.E. (2004). Audit Quality: A Synthesis of Theory and Empirical Evidence. Journal of Accounting Literature, 23(1): 153-193. 